\title{
Perception of Impacts of Climate Variability on Pastoralists and Their Adaptation/Coping Strategies in Fentale District of Oromia Region, Ethiopia
}

\author{
Muluken Mekuyie ${ }^{1^{*}}$ and Desta Mulu²
}

\begin{abstract}
Climate change has been threatening pastoral communities in Ethiopia as their economy is mainly based on rain-fed agriculture. The study area is one of the climate change prone area affected by climate induced shocks. To reduce the adverse effects of climate change, pastoral households need to recognize the changes already happening in their climate and employ climate change adaptation measures. Therefore, the present study was conducted in Fentale district, Central Ethiopia to determine the perceived adverse impacts of climate change and variability, the perception of pastoral households on the patterns of climate change and variability, and identify the adaptation/coping strategies of pastoralists to climate change impacts. A household questionnaire survey and focus group discussion were employed to collect primary data at a household level. A total of 130 pastoral households were sampled using random sampling. The data collected from household survey were analyzed using SPSS (version 20). The rainfall and temperature trends of the study area were analysed using Mann-Kendall test. The findings indicated significant decreasing trend of Belg rainfall and increasing trend of Kiremt rainfall for the period 1983-2017. The perception of pastoral households on rainfall and temperature trends was in line with the results of the recorded meteorological data analysis of the present study except the Kiremt rainfall and the long-term annual rainfall trends. The results indicated that pasture and water availability became scarce and livestock assets and productivity were highly reduced, due to adverse impacts of climate change and variability. The most important strategies deployed by the local people included (i) integrating livestock with crop production, (ii) livestock mobility, (iii) livestock diversification and herd composition change, (iv) decreased consumption, (v) remittance, (vi) cash for work and (vii) food aid. Therefore, the government should support and enhance household's indigenous adaptation strategies through the provision of market access, early warning information, affordable credit access, and development of water points.
\end{abstract}

Keywords: Adaptation, Climate, Livestock, Mobility, Pastoralist, Rainfall, Trend

\section{Introduction}

Nowadays, climate change is acknowledged as one of the most challenging and complex problem confronting the agricultural development worldwide (Tesfahunegn et al. 2016; IPCC 2014). However, agriculture production

\footnotetext{
*Correspondence: mulukenzeru@gmail.com

1 Wondo Genet College of Forestry and Natural Resources, Hawassa University, Shashemene, Ethiopia

Full list of author information is available at the end of the article
}

activities in Africa are generally more vulnerability to climate change than any other socioeconomic activities (Bonatti 2016; Elum et al. 2017). It is predicted that agriculture production in African will be decreased by $8 \%$ to $22 \%$ by 2050 (Schlenkerand and Lobell 2010). The continuous dry seasons experienced throughout the recent thirty years and the ongoing effects of El Niño in East African nations in general and Ethiopia specifically, made large number of people food insecure is due to climate 
change (Yayeh, 2017). Like other African countries, the agricultural sector in Ethiopia is prone to the impacts of climate change since the country's livelihood is mostly based on rain-fed agriculture (Burnett 2013; ISET 2013).

Ethiopia is a country located in the Horn of Africa experiencing a warming trend of annual temperature and increasing drought severity. The annual temperature of the country has been increasing by $0.37{ }^{\circ} \mathrm{C}$ every 10 years in the past 55 years (McSweeney et al. 2010; Tadege 2007). Ethiopia is one of the most vulnerable countries to climate change and variability in Africa, and is frequently confronted with climate-related hazards that affect the lives and livelihoods of people (World Bank 2010; Burnett 2013; ISET 2013). Climatic related shocks and stresses with drought and flood being the major one has affected agriculture sector in Ethiopia (Deressa et al. 2011). Although agriculture is contributing to Ethiopia about $45 \%$ of GDP, $60 \%$ of foreign exchange earnings and $80 \%$ of total employment, it is one of the most vulnerable sectors to the current and projected climate change, potentially exposing millions of people to recurrent food shortages (FAO 2007). This vulnerability is exacerbated by the existing poor socioeconomic conditions such as poor public services, population pressure, mounting poverty rate, political instability and food insecurity.

Pastoralists who reside in $61 \%$ of the country's landmass Pastoralist Forum Ethiopia [PFE] (PFE 1998), are highly vulnerable to climate change due to their location which is isolated, remote and underdeveloped and adversely affected by climate change and variability (Chibinga et al. 2012). The ecology in the region is fragile with an increasing trend of natural resources degradation while the pattern and distribution of rainfall has changed and become unpredictable (Nega et al. 2015). Fentale district in Central rift valley of Ethiopia is one of the pastoral areas in Ethiopia. The recurrent drought and chronic food insecurity in the study are of major concern by the federal and regional government and humanitarian organizations (Devereux 2006). Pastoral livelihood system of the area is vulnerable to the adverse impacts of climate change (Fratkin 2014) as their livelihood by itself relies on the basic natural resource such as water and pastures. Pastoral communities have been adapting to climate change for centuries. However, recently, due to the increasing trends of recurrent droughts and high rainfall variability along with the existing poor socio-economic characteristics, pastoralists have been becoming low adaptive to climate change and variability (Ayal and Leal Filho 2017).

Most studies on impacts of climate change on livelihood of people and their climate adaptation strategies are conducted in highland areas of Ethiopia where there is a relatively enabling environment for communities to respond better to the impacts of climate change (Deressa et al. 2011; Tadese and Alemayehu 2017; Temesgen et al. 2008). However, limited information is available in pastoral communities of the country particularly at local levels including the present study area (Nega et al. 2015). Therefore, understanding and documenting the impacts of climate change on pastoralists and their adaptation strategies is a crucial entry point to enhance the resilience of local communities to climate change. This study aimed to offer research evidence-based policy findings that would contribute to increasing pastoralists' capacity to adapt to the impact of climate change in Fentale district, East Shewa of Oromia region, Central Ethiopia.

The sub-objectives are to:

- Assess the perception of the local people on climate change and variability;

- Analyze the trends of climate change and variability using observed data.

- Assess the perceived impacts of climate change and variability on pastoralists;

- Identify local adaptation strategies to climate change and variability;

Research questions This study was guided by the following research questions:

i. What are the local people's perceptions about the region's climate change and variability and its impacts?

ii. What are the trends of climate change and variability in the study area?

iii. What are the perceived impacts of climate related shocks on pastoral communities?

iv. What are the adaptation strategies deployed by the local people to adapt or cope with climate change and variability?

\section{Materials and methods Study area description}

This study was conducted from September, 2018 to November, 2019 in Fentale district which is situated in East Shoa Zone of Oromiya regional state, Ethiopia (Goerner et al. 2009). Geographically the study area is located at $80^{\circ} 42^{\prime}$ to $90^{\circ} 00^{\prime} \mathrm{N}$ latitudes and $30^{\circ} 03^{\prime}$ to $40^{\circ} 01^{\prime} \mathrm{E}$ longitudes. The study area involves 1 administrative town, Metehara, located at a distance of $200 \mathrm{~km}$ from Addis Ababa and 18 rural villages (FWARDO 2007). The area involves undulating plains, hills and mountainous landscapes. The district's elevation varies from 862 m.a.s. 1 to 1997 m.a.s.l. Fentale district is characterized by arid and semi-arid environment. The mean minimum and 
mean maximum monthly temperature of the area varies from $12.80{ }^{\circ} \mathrm{C}$ to $21.90{ }^{\circ} \mathrm{C}$ and $28.0{ }^{\circ} \mathrm{C}$ to $36.70{ }^{\circ} \mathrm{C}$, respectively. The area receives an annual rainfall amount ranging from $400 \mathrm{~mm}$ to $700 \mathrm{~mm}$ (Ayalew 2001; CSA 2007). Livestock production is the main source of income for the communities in the district followed by mixed croplivestock production.

\section{Sampling methods}

This study employed purposive and stratified random sampling to select sample villages and households. Based on vulnerability to drought, water scarcity and representativeness of the livelihood activities in the area, three villages were selected out of 18 kebeles in Fentale district. These villages were Banti Mogassa, Kobo and Gelcha. Households in each village were stratified based on wealth status and a total of 130 respondents were selected randomly from the three villages. The sample size was determined by applying a simplified formula provided by Yamane (Yamane 1967) at 95\% confidence level and $5 \%$ percent level of precision.

$$
n=\frac{N}{1+N(e)^{2}} .
$$

where $\mathrm{n}$ is the sample size, $\mathrm{N}$ is the population size (total household heads size), and e is the level of precision.

\section{Methods of data collection}

Both primary and secondary sources of data were used in this study. Primary data was obtained through household surveys using structured questionnaire, Key Informant Interviews (KII) and Focus Group Discussions (FGDs). Secondary sources of data included meteorological agency for rainfall and temperature data collection, articles and thesis. A preliminary survey was carried out with local enumerators and key informants before the start of the actual survey, and the last questionnaire were modified and revised as needs be. The survey questionnaire was both open ended, dichotomous and multipleresponse type. The questionnaire was translated to the household's local language and data on different perspectives was gathered through household interview by the local field assistants.

A semi-structured questionnaire was administered through individual interviews with the heads of the selected households from December 2018 to April 2019. Data were gathered concerning household' annual income and sources of income, access to credit, health, socio-demographic profile, climate change information and adaptation and coping strategies. To complement the household questionnaire data, 15 individuals from sampled villages and various organisations were interviewed as key informants. Four focus group discussions were carried out from selected villages. The socioeconomic profile of households and their unit of measurements for the present study are indicated in Table 1.

\section{Determining trends of rainfall and temperature}

The rainfall and temperature time series data were collected from Ethiopian National Meteorological Agency [NMA] for the period 1983-2017 (Ethiopian National Meteorology Agency (NMA) 1983-2017). The seasonal and annual temporally distributed rainfall and temperature data trends were analysed using the Mann-Kendall statistical test at $0.1 \%, 1 \%$ and $5 \%$ level of significance. The Mann-Kendall test for monotonic analysis of trend together with nonparametric Sen's Slope Estimator can be used to estimate the magnitude of trend for time series data which are not normally distributed (Babar and Ramesh 2013; Hamed 2008; Mondal et al. 2012). The Mann-Kendall test $\mathrm{t}$ is a non-parametric statistical procedure that is well-suited for analysing trends in data over time. A non-parametric test is preferred over the parametric in view of its ability for analysis of data that is not normally distributed (Babar and Ramesh 2013; Mondal et al. 2012).

The seasonal and annual rainfall distribution was analysed following Oliver's (1980) precipitation concentration index (PCI) equation. Rainfall totals on monthly, seasonal or annual sales are key components influencing water accessibility. However, precipitation concentration in time likewise plays a significant role. Different indices have been used to assess the precipitation concentration and among these the Precipitation Concentration Index [PCI] (Oliver 1980) is suggested, as it gives information on long-term total variability in the quantity of precipitation received. The Precipitation

\begin{tabular}{|c|c|}
\hline $\begin{array}{l}\text { Socioeconomic profile } \\
\text { of households }\end{array}$ & Description \\
\hline Gender & Dummy, $1=$ male and $0=$ female \\
\hline Age & Continuous \\
\hline Level of education & Continuous \\
\hline Family size & Continuous \\
\hline Farm size & Continuous \\
\hline Livestock ownership & Continuous \\
\hline Total annual income & Continuous \\
\hline Distance to the market & Continuous \\
\hline Access to extension & Dummy, $1=$ yes, $0=$ no \\
\hline Access to climate information & Dummy, $1=$ yes, $0=$ no \\
\hline Access to credit & Dummy, $1=$ yes, $0=$ no \\
\hline
\end{tabular}


Concentration Index (PCI) is a robust indicator of the temporal distribution of rainfall. The equation to calculate PCI at annual scale is described as follows:

$$
P C I_{\text {annual }}=\frac{\sum_{i=1}^{12} P i^{2}}{\left(\sum_{i=1}^{12} p i\right)^{2}} \times 100
$$

where:

$\mathrm{Pi}=$ the rainfall amount of the ith month.

$\Sigma=$ summation over the 12 months.

According to Oliver (1980), the rainfall is uniformly distributed if the PCI value is less than 10. If the PCI values are in the range of 11-20, then it indicates the irregular distribution of rainfall, and values above 21 indicate a very irregular rainfall distribution.

The inter-annual and seasonal fluctuations of rainfall and drought severity were estimated using the Standardised Precipitation Index (SPI) by McKee et al. (1995). The SPI estimation for any area is depending on the long-term rainfall record for a given period. The long-term rainfall record is fitted to a gamma distribution as it has been found to fit the precipitation distribution well. The gamma distribution parameters are estimated using the maximum likelihood. The gamma cumulative probability gamma function is then transformed into a standard normal random variable $\mathrm{Z}$ with mean of zero and standard deviation of 1 (Edwards 1997). Positives SPI values reveal greater than average rainfall and negative values show less than average rainfall. Since the SPI is normalized, drier and wetter periods can be estimated in the same way. A drought starts when the SPI value becomes negative and ends when it becomes positive. The drought severity (magnitude) is then the aggregate values of SPI within the duration of drought (McKee et al. 1993). The SPI values are indicated in Table 2 below.

This indicator was produced by McKee et al. (1993) and since then has been employed widely in various regions across the globe, including the United States (Hayes et al. 1999), Australia (Barros and Bowden 2008), Europe (Cancelliere et al. 2007).

Table 2 Drought classes and corresponding standardized precipitation index values

\begin{tabular}{ll}
\hline SPI values & Drought classes \\
\hline$\geq 0$ & No drought \\
0 to -0.99 & Mild drought \\
-1.00 to -1.49 & Moderate drought \\
-1.5 to -1.99 & Severe drought \\
$\leq-2$ & Extreme drought
\end{tabular}

Source: McKee et al. (1993)

\section{Results}

Socio-economic and institutional characteristics

of households

Table 3 presents the average age, sex, and access to basic services of households. The average age of household heads was 43 years and a large portion of them were seen as male (60\%). An extensive number of the respondents $(72.2 \%)$ were seen as illiterate, which implies that only $28.8 \%$ of the respondents could read and write with a formal education extending from 1 to 10 years. Besides, the outcomes uncovered that only $32 \%$ of households had access to extension services, implying that access to extension services in the study area was very low. The findings further indicated that households' access to credit was very low in the study area. About $20 \%$ of households had access to credit. And, only $15 \%$ and $8 \%$ of households got formal market and climate information respectively through district extension experts and the radio. The findings showed that the average size of the family in the study area was 6.5. This was generally higher than the national average family size (5.1).

Livestock play a central role in determining the wealth and social status of pastoralists. The mean livestock size of households was 29.87 Tropical Livestock Unit (TLU) with standard deviation of 4.37. Moreover, the results indicated that the average farmland size of households was $1.6 \pm 0.5$ ha. The findings indicated that the overall mean annual income of the households was $118890.6 \pm 5742$ Ethiopian Birr (EB).

\section{Local household's perception on climate change and variability}

In this study, perceptions of pastoral households were assessed on the trends of rainfall and temperature two/ three decades ago. Ninety-eight percent of the respondents perceived that the rainfall has declined; rainfall comes early/late and ceases short from the normal rainy season, while $95 \%$ of the households clarified that

Table 3 Status of households regarding sex, education and access to basic services

\begin{tabular}{lll}
\hline Description & Households states & Percentage \\
\hline Sex & Male headed households & 60 \\
& Female headed households & 40 \\
Education & Illiterates & 72.2 \\
& Read and write & 28.8 \\
Access to basic services & Access to credit & 20 \\
& Access to market & 15 \\
& Access to climate information & 8 \\
& access to extension & 32 \\
\hline
\end{tabular}


the temperature has increased. Moreover, the findings indicated that there have been frequent droughts in the study areas as explained by $100 \%$ of the sampled households. As perceived by local respondents, the rising temperature, frequent drought occurrence and decreased Belg rainfall was in agreement with the findings of the observed data analysis. Notwithstanding, the Kiremt and long-term annual rainfall was not in accordance with their perception. In this study, the Belg rainfall occurs from March-April and the Kiremt rainfall occurs from July-September.

\section{Trends of rainfall and temperature}

The findings indicated that significant decreasing trend of Belg rainfall $(-3.0 \mathrm{~mm}$ per season) and increasing trend of Kiremt rainfall (2.0 mm per season) was observed for the period 1983-2017 (at $\alpha=0.05$ ) in the study area. The significant decreasing trend of Belg rainfall implies a reflection of disastrous effects on Fentale pastoralists as they are dependent on the seasonal availability of rainfall to access forage and water for their livestock. The results revealed that the long-term rainfall trend was not significant. The PCI analysis showed that rainfall distribution in the area was highly irregular. Besides, the SPI analysis indicated that around 16 years of the observed period 1983-2017 were characterized by below average rainfall (Fig. 1). It was observed that 1 extreme drought, 2 severe drought, 2 moderate droughts, 13 mild droughts occurred in the study area for the observation period. The findings uncovered a significant increasing trend of monthly, seasonal and annual temperatures, involving mean, maximum and minimum temperatures.

\section{Impacts of climate change and variability}

\section{Decreased livestock assets and productivity}

The majority of the respondents (90\%) responded that the recurrent and prolonged droughts decreased number of livestock and productivity. The respondents complained that on average, the number of livestock per household under normal years was 44.2 Tropical Livestock Unit (TLU). However, recently, the number of livestock per household was 29.87 TLU. Besides, the results indicated that the drought also decreased the amount of yield per animal. For instance, during normal conditions, four to eight individuals were supported by one lactating cow, while recently; only two individuals can be supported by one lactating cow. This was related with the decrease in the milking time per day and decrease of milk yield per milking time. Under normal conditions, a lactating cow can be milked three times per day, but recently only once or twice per day. Results from FGD and KII indicated that climate variability and change affected the productive and reproductive performances of livestock and consequently their population growth through its effects on the quantity and quality of pastures and water availability in addition to increasing heat stresses.

\section{Decreased forage availability}

The majority of the respondents (92\%) complained that since the magnitude of drought has increased, the rangeland has been degraded and the palatable forages have recently been replaced by non-palatable plants. Respondents noted that before the grazing area recovered from the previous drought, another drought affected the new growth. This situation could cause loss of palatable forage species from the rangeland and reduces forage availability. Key informants also complained that as the dry season grazing areas deteriorated due to frequent droughts and unreliable and erratic rains, pastoralists concentrate their livestock around water points such as along the sides of perennial rivers, which in turn led to overgrazing of the existing forage resources. Consequently, overgrazing leads to expansion of low forage valued plants or unpalatable species around water points.

\section{Drying up of water points}

Eighty-five percent of respondents clarified that water points have either dried up or supply was diminished

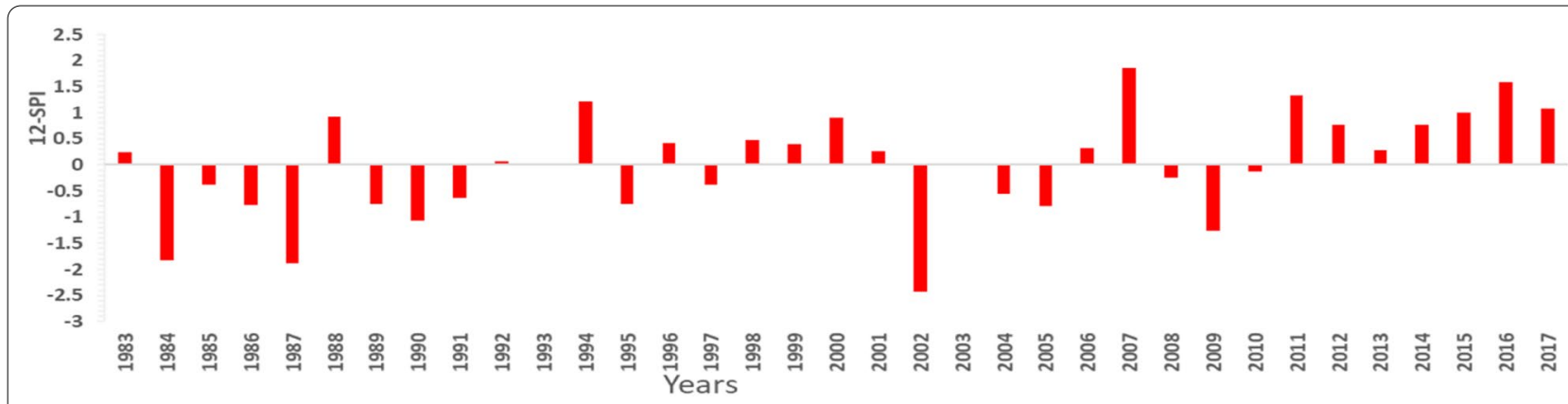

Fig. 1 Twelve-months SPI in Fentale district for 1983-2017. Source: Author's own result 
over the course of the recent decades. The shallow wells, ponds and cisterns were the main sources of water for pastoralists. The local households complained that they travelled long distances, more than $20 \mathrm{~km}$, to get water from perennial rivers, even during normal dry seasons of the year. KII indicated that water shortage was turning into a significant disaster risk for Fentale pastoralists because of the drying up of many water points related with frequent droughts.

\section{Effects on households' terms of exchange}

Ninety percent of the respondents affirmed that during droughts, pastoralists had been compelled to sell their livestock at low price because of poor body conditions of animals and oversupply. In recent years, drought frequency has increased, droughts occurred every two three years and pastoralists had no time to recover from the effects of the past drought and, subsequently, the price of livestock continued to decrease while the food grain price was increasing.

Recently, as indicated by local households, livestock assets and their yields have essentially decreased because of climate change and variability. Pastoral households raise livestock, basically for trade of grains and manufactured goods for their survival. Ninety percent of the respondents affirmed that during droughts, pastoralists had been compelled to sell their livestock at low price because of poor body conditions of animals and oversupply. Households noted three decades back, price of inputs and outputs were fair as pastoralists begun to get an adequate amount for animal products. In recent years, drought frequency has increased, droughts occurred every two three years and pastoralists had no time to recover from the effects of the past drought and, subsequently, the price of livestock continued to decrease while the food grain price was increasing. Results from FGD and KII revealed that recently, the rainfall begun late and stopped early and/or it would rain for a couple of days with high intensity and afterward vanish, which isn't adequate for the growth of pastures and, hence, livestock assets still continue to diminish while the price of grains is rising. Overall, climate change and variability in terms of recurrent drought, short rainy days, changes in the timing of rainfall and erratic nature of rainfall and lack of market information and access lead to negative terms of exchange and threats the resilience of pastoralism in Fentale district.

\section{Adaptation and coping strategies of fentale pastoralists}

The major adaptation and coping strategies of pastoral households to adapt to adverse effects of climate variability are indicated in Fig. 2.

\section{Integrating livestock with crop production}

Since livestock assets and productivity decreased over time, some households begun crop farming using smallscale irrigation along the banks of the Awash River. The results showed that some pastoral households (25\%) practiced small-scale crop cultivation using traditional irrigation practices such as furrows and channels using ground gravity (Fig. 2).

\section{Livestock diversification and herd composition change}

Herd composition change and diversification were important strategies employed by the local pastoral households to adapt to the changing climate. As reported by majority of the local respondents (72\%), over the previous years the types of herds kept by pastoralists were cattle, camels, sheep, goats, donkeys, mules and horses. The prevailing number of the herd was cattle during the

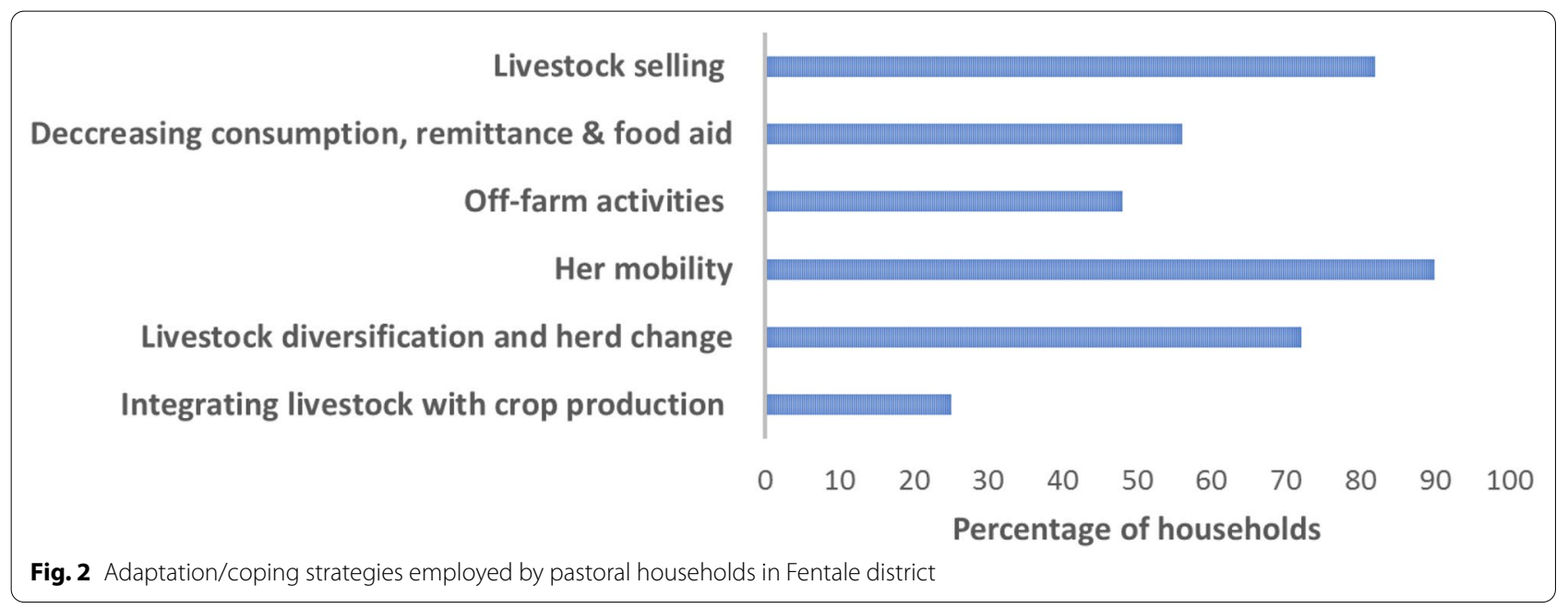


past times when grass availability was copious. During the survey period, no households were observed having mules and horses, while donkeys were rarely kept by a small number of households. The findings indicated that goats were the dominant population in the herd, followed by camels. The numbers of cattle possessed were exceptionally small when compared with number of goats and camels. The respondents noticed that the explanation behind huge numbers of goats and camels was that camels and goats are tolerant to the effects of drought and can survive on browsing trees and bushes during feed shortage, while keeping large number of cattle was difficult since palatable forages have been lost due to frequent and prolonged droughts.

\section{Livestock mobility}

Herd mobility was a key strategy deployed by pastoralists because of feed and water deficiency in the study area. The KII noticed that forage availability was highly variable, both temporally and spatially, and in light of their experience they knew where and when the forages were available. The local households $(90 \%)$ detailed that forages were temporally available and particularly the type of forages in the area were short-lived. Hence, before the forages disappear, the pastoralists would move their livestock on time and on the right place to use these shortlived forages. This showed that mobility was a main strategy for pastoralists in light of the seasonal, annual and spatial variability of forages and water.

\section{Off-farm activities}

The findings showed that cash-for-work was the main off-farm activity practiced by $48 \%$ pastoral households in the Fentale district (Fig. 2). The cash-for-work programme which was offered by humanitarian assistance organisations gave temporary employment for the poor pastoralists. The second prevailing off-farm activity was charcoal and firewood selling. The other off-farm activities pursued by $23 \%$ of households were petty trading for, example, shopping, livestock and khat trading.

\section{Decreasing consumption, remittance and food aid}

Fifty-six percent of the households indicated that in response to food deficiencies, pastoralists reduce their number of meals per day (Fig. 2). As indicated by the local people, during the most exceedingly awful occasions of the year some adult households ate only one meal per day (41\%), others two meals per day $(54 \%)$ and very few adult households had three meals per day (5\%). With respect to kids' food consumption, most kids (68\%) had only two meals per day and $32 \%$ three meals per day. The households further indicated that during the drought, the pastoral households diminished the expenditure for clothing, social events and medication.

\section{Livestock selling}

The findings showed that $82 \%$ of pastoralists were involved in livestock selling within the 12 months preceding the survey period. Livestock selling is normal in the study area so as to satisfy their requirements; however, most households had been compelled to sell their livestock during the drought periods as the necessity for food grains raised because of the decrease of milk and butter yields from their cows and camels.

\section{Discussion}

In the present study, the average family size (6.5) was generally higher than the national average family size. Such enormous family size in the area may be connected with the polygamy culture that is commonly practiced in Fentale district. Similar results were reported in the studies conducted in Afar region and Sidama zone, Ethiopia (Muluken et al. 2019; Hameso 2015). Besides, the result indicated that $97 \%$ of households were in the range of 28 to 64 years old implying that they were in the productive age category. The result is similar with the studies conducted in Sidama zone, southern Ethiopia which indicated that $96 \%$ of farmers in their study area were in the productive age category (Davies et al. 2009). This study revealed that household's level of education was very low, $72.2 \%$ illiterates and $28.8 \%$ literates. This implies that the vulnerability of communities to climate variability and change in the study area was high as illiterate households are reluctant to adopt new adaptive technologies and have low employment opportunities on non-farm activities as compared to their counterparts. This result is supported by the studies conducted in Afar region and dry lands of Africa which indicated that education enhances household's resilience to climate-induced shocks and stresses (Muluken et al. 2019; Kebede and Adane 2011). Furthermore, basic services such as access to credit, market, climate information and extension services in the study area was very poor which could decrease the adaptive capacity of households to climate induced shocks. This result is in line with a study conducted in Africa which revealed that poor access to basic services reduces the capacity of rural households to diversify their livelihood strategies in light of climate change induced shocks (Hassan and Nhemachena 2008).

On the other hand, this study also looked into perception of pastoral households to climate variability and change which is paramount to local decision makers to introduce appropriate adaptation measures and enhance climate resilience of the local people (Maddison 2006; Arsiso et al. 2017). Accordingly, 98\% of pastoral 
households perceived that the rainfall has decreased; rainfall comes early/late and ceases short from the normal rainy season, while $95 \%$ of the respondents complained that the temperature has increased. Besides, the results showed that there have been frequent droughts in the study areas as complained by $100 \%$ of the respondents. The result is in line with the studies conducted in Borana, Southern Ethiopia; Southern and Central Tigray and in Quara district, Gonder, northern Ethiopia Nega et al. 2015; Gedefaw et al. 2018). The perception of local people on Belg rainfall, temperature and frequency of drought was in line with the results of the observed data analysis. However, their perception on trends of Kiremt rainfall contradicted with the findings of meteorological data analysis. In the present study, the results of the meteorological data analysis indicated significant decreasing trend of Belg rainfall, increasing trend of Kiremt rainfall, significant increasing trend of seasonal and annual temperatures and occurrence of 1 extreme drought, 2 severe drought, 2 moderate droughts, 13 mild droughts for the period 1983-2017 (at $\alpha=0.05$ ). Evidence of decreasing trends of rainfall in the Belg rainfall in Ethiopia was also indicated by Jury and Funk (2013), Seleshi and Camberlin (2006), Williams and Funk (2011). However, the analysis was inconsistent with the findings indicated by Seleshi and Zanke (2004) who indicated that the seasonal rainfall trends in the central, northern and north-western parts of Ethiopia was non-significant during the period 1965-2002. The result is in agreement with the results of Conway and Schipper (2011), Demeke et al. (2011) and Roselle et al. (2011) who showed that rainfall anomaly, particularly droughts, have been increasing and were the main reason for food insecurity and famine in Ethiopia. Moreover, the results revealed that the seasonal and annual rainfall distribution was highly irregular in the study area. This study is in line with the findings of Hadgu et al. (2013) who reported irregular distribution of rainfall in northern Ethiopia. Consequently, the significant declining trend of Belg rainfall allied with its irregular rainfall distribution and increased temperature trends could have an adverse impact on Fentale pastoralists as they are reliant on the seasonal availability of rainfall to access forage and water for their livestock. Similar studies were reported in Ethiopia and other eastern African countries (Bewket and Conway 2007; Ellis and Swift 1988)

This study also identified perceived impacts of climate variability on pastoral households in Fentale district. Accordingly, majority of households (90\%) experienced decreased number of livestock and productivity associated with recurrent droughts and disease outbreaks. Comparable findings were reported in a study conducted in southern low lands of Ethiopia which revealed that rate of livestock reproduction and productivity have been declining from time to time in pastoral communities, due to the negative effects of climate related shocks, particularly drought (Amsalu and Adem 2009). The local people (92\%) further complained that the rangeland had become degraded and replaced by unpalatable species as a result of declining rainfall and recurrent droughts leading to scarcity of livestock feed. This result is in agreement with a study conducted in Fentale Pastoral Woreda of Oromia Regional State, Ethiopia which revealed that the increased magnitude of the drought negatively affected availability of palatable grasses and browse (Bekele and Amsalu 2012). As reported by $90 \%$ of respondents, due to the drying up of watering points and feed scarcity, livestock have been becoming very emaciated and couldn't be sold at reasonable price. Hence, the price of livestock continued to decrease while the food grain price was increasing in the study area. Similar results were found which revealed that the price of livestock decreased by $50-60 \%$, related with the drought of 2002 , while the price of maize raised by about 235\% (Davies and Bennett 2007).

Furthermore, this study assessed the main adaptation and coping strategies employed by the local pastoral households in the face of climate change and variability. Accordingly, the results indicated that mixed croplivestock production, livestock diversification and herd change, mobility, off-farm activities, decreasing consumption, remittance and food aid and livestock selling were the main strategies adopted by the local people to adapt and cope with climate change induced shocks. The results are in line with the studies conducted in Borana region, southern Ethiopia and other horn of Africa (Habtamu 2012; Mengistu 2016).

This study implies that rainfall has been becoming more variable and Belg season rainfall showed a significant declined trend, drought frequency and temperature of the study area have been increasing indicating sustainability of pastoralism as livelihood for pastoral households in the study is becoming at greater risk. Hence, the local decision makers and other concerned partners should develop and introduce appropriate adaptive strategies to reduce the adverse effects associated with recurrent droughts, rainfall variability and increasing temperatures. The survey results indicated that mixed crop-livestock using small scale irrigation, herd mobility and livestock diversification were the main adaptation strategies adopted by the local pastoral households. Therefore, households should be provided with improved agricultural technologies such as a water pump for irrigation, and improved seed varieties with short growing periods and resistant to diseases. It is also paramount to support those households who adopted herd mobility as 
adaptation strategy such as reducing conflicts with neighboring ethnic groups (Afar and Somali ethnic groups) and improving peace among them. In this study, access to credit, market, education, extension services and climate information was very low. Hence, there is a need to improve these basic public services if pastoral households need to be climate resilient. Further study is required to explore constraints of adaptation strategies and factors that increases vulnerability of pastoral households to climate induced shocks.

\section{Conclusion}

This study confirmed that long-term reduced trend of Belg rainfall, recurrent droughts, rainfall variability and increased temperature along with household's poor access to basic services adversely affected pastoralists. There is a need to improve access to basic services if pastoralists need to be climate resilient. Therefore, the local decision makers and other partners should develop appropriate adaptation strategy to climate change induced shocks such as enhancing and scale up of irrigation crop farming.

\section{Abbreviations \\ CSA: Central Statistical Agency; FAO: Food and Agriculture Organisation; FWARDO: Fentale Woreda Agriculture and Rural Development Office; IPCC: Intergovernmental Panel on Climate Change; NMA: National Meteorological Agency; PCl: Precipitation Concentration Index; SPI: Standardized Precipitation Index; TLU: International Livestock Unit; UN-EUE: United Nations Emergencies Unit for Ethiopia.}

\section{Acknowledgements}

The authors are thankful to local-level government offices, farmers, and enumerators for their time and cooperation during field data collection.

\section{Authors' contributions}

MM designed the data collection tools, undertook fieldwork and most of the analysis, and developed the manuscript. DM participated on data collection and writing-up of findings and made editorial comments on the draft manuscript. All authors read and approved the final manuscript.

\section{Funding}

The authors are grateful to Wondo Genet College of Forestry and Natural Resource for the financial support offered for this study.

\section{Availability of data and materials}

All data generated during analsed during this study are included in this article.

Ethics approval and consent to participate

Not applicable.

\section{Consent for publication}

Not applicable.

\section{Competing interests}

The Authors declare that they have no competing interests.

\section{Author details}

${ }^{1}$ Wondo Genet College of Forestry and Natural Resources, Hawassa University, Shashemene, Ethiopia. ${ }^{2}$ Forestry and Climate Science, College of Agriculture, Injibara University, Injibara, Ethiopia.
Received: 16 October 2020 Accepted: 14 December 2020

Published online: 12 January 2021

\section{References}

Amsalu A, Adem A 2009 Assessment of climate change-induced hazards, impacts and responses in the southern lowlands of Ethiopia. Addis Ababa Forum for Social Studies/Cordaid. http://publication.eiar.gov. et:8080/xmlui/bitstream/handle/123456789/3075/36.pdf1abbyyy .pdf?isAllowed $=y \&$ sequence $=1$

Arsiso BK, Tsidu GM, Stoffberg GH, Tadesse T (2017) Climate change and population growth impacts on surface water supply and demand of Addis Ababa, Ethiopia. Climate Risk Manag 18:21-33. https://doi.org/10.1016/j. crm.2017.08.004

Ayal DY, Leal Filho W (2017) Farmers' perceptions of climate variability and its adverse impacts on crop and livestock production in Ethiopia. J Arid Environ 140:20-28

Ayalew G (2001) Pastoralism under Pressure: Land alienation and Pastoral Transformation among Karrayu of Eastern Ethiopia, 1941 to the present. The Shaker Publishing, The Hague

Babar SF, Ramesh H (2013) Analysis of south west monsoon rainfall trend using statistical techniques over Nethravathi basin. Int J Adv Technol Civil Engin 2(1):130-136

Bekele, A. \& Amsalu, A. 2012. Household responses to drought in Fentale Pastoral Woreda of Oromia Regional State, Ethiopia. Int J Econ Develop Res and Investment, 3(2):36-52. https://pdfs.semanticscholar.org/2f24/00c41 ab20b07f2c4c16e3cd952ea959e1a02.pdf

Bewket W, Conway D (2007) A note on the temporal and spatial variability of rainfall in the drought-prone Amhara region of Ethiopia. Int J Climatol 27(11):1467-1477. https://doi.org/10.1002/joc.1481

Bonatti M (2016) Land use policy climate vulnerability and contrasting climate perceptions as an element for the development of community adaptation strategies: case studies in Southern Brazil. Land Use Policy 58:114-122

Burnett, D. 2013. Stage 2-supporting climate resilient value chains. In: Final Report: Stage 2-supporting Climate Resilient Value Chains

Cancelliere A, Di Mauro G, Bonaccorso B, Rossi G (2007) Stochastic forecasting of drought indices. In: Rossi G, Vega T, Bonaccorso B (eds) Methods and tools for drought analysis and management. Springer, Netherlands, pp 83-100

Chibinga OC, Musimba NRK, Nyangito MM, Simbaya J, Daura MT (2012) Climate variability; enhancing adaptive utilization of browse trees for improved livestock production among agro-pastoralists communities in Southern Zambia. African J Environ Sci Technol 6(7):267-274

Conway D, Schipper ELF (2011) Adaptation to climate change in Africa: challenges and opportunities identified from Ethiopia. Global Environ Change 21(1):227-237

CSA (Central Statistical Agency) (2007) Summary and statistical report of the (2007) Population and Housing Census. Addis Ababa, Ethiopia

Davies J, Bennett R (2007) Livelihood adaptation to risk: constraints and opportunities for pastoral development in Ethiopia's Afar region. J Develop Stud 43(3):490-511. https://doi.org/10.1080/00220380701204422

Davies, M., Guenther, B., Leavy, J., Mitchell, T. \& Tanner, T. 2009. Climate change adaptation, disaster risk reduction and social protection: complementary roles in agriculture and rural growth? IDS Working Papers, 2009(320):01-37. https://doi.org/10.1111/j.2040-0209.2009.00320_2.x

Demeke AB, Keil A, Zeller M (2011) Using panel data to estimate the effect of rainfall shocks on smallholder's food security and vulnerability in rural Ethiopia. Climatic change 108(1-2):185-206

Deressa TT, Hassan RM, Ringler C (2011) Perception of and adaptation to climate change by farmers in the Nile basin of Ethiopia. J Agric Sci 149(1):23-31

Devereux S (2006) Vulnerable livelihoods in Somali region, Ethiopia. Institute of Development Studies, Brighton

Edwards, D.C. 1997. Characteristics of 20th century drought in the United States at multiple time scales (No. AFIT-97-051). AIR FORCE INST OF TECH WRIGHTPATTERSON AFB OH

Ellis, J. \& Swift, D. M.1988. Stability of African pastoral ecosystems: Alternate paradigms and implications for development. J Range Management 
Archives, 41 (6):450-459. https://journals.uair.arizona.edu/index.php/jrm/ article/view/8307/7919

Elum ZA, David MM, Ana M (2017) Climate risk management farmer's perception of climate change and responsive strategies in three selected provinces of South Africa. Climate Risk Management 16:246-257

Ethiopian National Meteorology Agency [NMA] (1983-2017). Rainfall and Temperature data records for Fentalle district, Ethiopian National Meteorology Agency, Addis Ababa, Ethiopia

Food and Agricultural Organization (FAO). 2007. Adaptation to climatic change in agriculture, forestry and fisheries: perspectives, frameworks and practices

Fratkin E (2014) Ethiopia's pastoralist policies: development, displacement and resettlement. Nomadic Peoples 18(1):94-114

FWARDO (Fentale Woreda Agriculture and Rural Development Office). 2007. Fentale Woreda Agriculture and Rural Development Office. Unpublished annual report, June 2007, Metehara

Gedefaw, Yan D, Wang H, Qin T, Girma A, Abiyu A, Batsuren D (2018) Innovative trend analysis of annual and seasonal rainfall variability in Amhara regional state. Ethiopia. Atmosphere 9(9):326. https://doi.org/10.3390/ atmos 9090326

Goerner A, Jolie E, Gloaguen R (2009) Non-climatic growth of the saline Lake Beseka, main Ethiopian rift. J Arid Environ 73(3):287-295

Habtamu L (2012) Domestic animal biodiversity in Ethiopia and its threats and opportunities with emphasis to changing climate: an overview. Adv Life Sci Techol 6:33-39

Hadgu, G., Tesfaye, K., Mamo, G. \& Kassa, B., 2013. Trend and variability of rainfall in Tigray, northern Ethiopia: analysis of meteorological data and farmers' perception. Academia

Hamed K (2008) Trend detection in hydrologic data: the Mann-Kendall trend test under the scaling hypothesis. J Hydrol 349(3-4):350-363

Hameso, S., 2015. Perceptions, vulnerability and adaptation to climate change in Ethiopia: The case of smallholder farmers in Sidama. American Journal of Climate Change, 8(2)

Hassan R, Nhemachena C (2008) Determinants of African farmers'strategies for adapting to climate change: Multinomial choice analysis. African JAgric Resour Econ 2(311-2016-5521), pp.83-104. file:///C:/Users/NTGT/ Downloads/Determinants_of_African_farmers_strategies_for_ad.pdf

Hayes MJ, Svodoba MD, Wilhite DA, Vanyarkho OV 1999 Monitoring the 1996 drought using the standardised precipitation index. Bulletin of the American Meteorological Society. 80(3):429. J Agric Res 1(6): 88-100

Institute for Social and Environmental Transition (ISET) (2013) Simple Scaled Climate Projections \& Their Potential Implication for Jijiga. Institute for Social and Environmental Transition- International Boulder, Ethiopia

IPCC (Intergovernmental Panel on Climate Change). 2014. Climate Change 2014: Impacts, adaptation, and vulnerability: Regional Aspects. Working Group II Contribution to the Fifth Assessment Report of the Intergovernmental Panel on Climate Change. [Field, C.B., V.R. Barros, D.J. Dokken, K.J. Mach, M.D. Mastrandrea, T.E. Bilir, M. Chatterjee, K.L. Ebi, Y.O. Estrada, R.C. Genova, B. Girma, E.S. Kissel, A.N. Levy, S. MacCracken, P.R. Mastrandrea, and L.L.White (eds.)]. United Kingdom: Cambridge University Press

Jury MR, Funk C (2013) Climatic trends over Ethiopia: regional signals and drivers. Int J Climatol 33(8):1924-1935

Kebede D, Adane H 2011 Climate change adaptations and induced farming livelihoods. Dry lands oordination Group Report No, p.64. https://www. utviklingsfondet.no/dcg/assets/documents/Publications/1059-dcg_ report_no._64.pdfC

Maddison. 2006. Perception and adaptation to climate change in Africa. CEEPA Discussion Paper No. 10. Centre for Environmental Economics and Policy in Africa, University of Pretor. Source Economics, 2: 83-104. Doi 10.4236/ as.2015.612140

McKee T, Doeske N, Kleist J 1993 Drought monitoring with multiple time scales. In: Proceedings of the Ninth Conference on Applied Climatology Dallas, Boston, MA: American Meteorological Society, pp. 233-236
McSweeney C, Lizcano G, New M, Lu X 2010 The UNDP climate change country profiles: improving the accessibility of observed and projected climate information for studies of climate change in developing countries, American meteorological society. https://doi.org/10.1175/2009bams2826.1

Mengistu D 2016 Traditional Coping Strategies of Borana Pastoralists for Climate Extremes: A case of Yabello District, Borana Zone, Ethiopia. Int J Engin Innovations Res 5(3), p.210. https://www.researchgate.net/publi cation/328175538

Mondal A, Kundu S, Mukhopadhyay A (2012) Rainfall trend analysis by MannKendall test: a case study of north-eastern part of Cuttack district, Orissa. Int J Geol Earth Environ Sci 2(1):70-78

Muluken F, Jordaan A, Melka Y 2019 Vulnerability of Southern Afar pastoralists to climate variability and change, Ethiopia. Jàmbá: J Disaster Risk Studies 11(1), pp.1-8

Nega D, Mohammed C, Bridle K, Corkrey R, McNeil D (2015) Perception of climate change and its impact by smallholders in pastoral/agropastoral systems of Borana. South Ethiopia. SpringerPlus 4(1):236

Oliver J (1980) Monthly precipitation distribution: a comparative index. Professional Geographer 32(3):300-309

Pastoralist Forum Ethiopia (PFE) (1998) Pastoralism and Land: Land Tenure, Administration and Use in Pastoral Areas of Ethiopia. Addis Ababa, Ethiopia. Puigdefabregas, J. 1998. Ecological impacts of global climate change on dry lands and their implications for desertification. Land Degrad Dev 9:393406

Rosell S (2011) Regional perspective on rainfall change and variability in the central highlands of Ethiopia, 1978-2007. Appl Geogr 31 (1):329-338

Schlenker W, Lobell DB (2010) Robust negative impacts of climate change on African agriculture. Environ Res Lett 5(1):014010

Seleshi Y, Camberlin P (2006) Recent changes in dry spell and extreme rainfall events in Ethiopia. Theoret Appl Climatol 83(1-4):181-191

Seleshi Y, Sanke U (2004) Recent changes in rainfall and rainy days in Ethiopia. Int J Climatol 24(8):973-983

Tadege A (2007) Climate change national adaptation program of action (NAPA) of Ethiopia. National Meteorological Agency, Addis Ababa

Tadese A, Alemayehu M 2017 Impacts of Climate Change on Food Security and its Adaptation and Mitigation Options in Ethiopia: A Review. Impact of El Niño on Biodiversity, Agriculture, and Food Security 23-24 February 2017 Haramaya University, Ethiopia, p.75

Temesgen D, Claudia R, Mahmud Y, Rashid M, Tekie A 2008 Analyzing the Determinants of Farmers' Choice of Adaptation Methods and Perceptions of Climate Change in the Nile Basin of Ethiopia. IFPRI. Discussion Paper No 00798 Washington, DC

Tesfahunegn G, Mekonen K, Tekle A (2016) Farmers'perception on causes, indicators and determinants of climate change in northern Ethiopia: implication for developing adaptation strategies. Appl Geogr 73:1-12

Williams A, Funk C (2011) A westward extension of the warm pool leads to a westward extension of the Walker circulation, drying eastern Africa. Clim Dyn 37(11-12):2417-2435

World Bank. 2010. The social dimensions of adaptation to climate change in Ethiopia. Development and climate change discussion papers No. 14 Washington, DC. USA

Yamane T (1967) Statistics, an introductory analysis, 2nd edn. Harper and Row Inc., New York, p 345p

Yayeh D (2017) Farmers' perceptions of climate variability and its adverse impacts on crop and livestock production in Ethiopia. J Arid Environ 140:20-28

\section{Publisher's Note}

Springer Nature remains neutral with regard to jurisdictional claims in published maps and institutional affiliations. 